\title{
Persistent HIV antigenaemia and decline of HIV core antibodies associated with transition to AIDS
}

\author{
JOEP M A LANGE, DEBORAH A PAUL, HAN G HUISMAN, FRANK DE WOLF, \\ HENK VAN DEN BERG, ROEL A COUTINHO, SVEN A DANNER, JAN VAN DER NOORDAA, \\ JAAP GOUDSMIT
}

\begin{abstract}
Sequential serum samples from 13 homosexual men who seroconverted for antibodies to human immunodeficiency virus (HIV) were tested for HIV antigen. In one of these men, who developed the acquired immune deficiency syndrome (AIDS), HIV antigenaemia preceded the onset of AIDS by more than a year and persisted throughout the course of the disease. This antigenaemia was accompanied by the disappearance of IgG antibody reactivity to the major HIV core protein p24. In none of the 12 others, who all remained without serious disease, were serum concentrations of HIV antigen detected, except on one occasion in one man. All their serum samples showed strong IgG antibody reactivity to $\mathrm{p} 24$.

Nine children who were infected with HIV in 1981 by plasma
\end{abstract} transfusion from a single donor were also followed up for HIV

Departments of Virology and Internal Medicine, Academic Medical Centre, University of Amsterdam, The Netherlands

JOEP M A LANGE, MD, internist

FRANK DE WOLF, MD, research fellow

SVEN A DANNER, MD, PHD, internist and head of AIDS unit

JAN VAN DER NOORDAA, MD, PHD, virologist and head of virology department JAAP GOUDSMIT, MD, PHD, virologist

Abbott Laboratories, Diagnostic Division, North Chicago, Illinois, United States

DEBORAH A PAUL, PHD, biochemist

Central Laboratory of The Netherlands Red Cross Blood Transfusion Service, Amsterdam, The Netherlands

HAN G HUISMAN, PHD, molecular biologist

Department of Paediatrics, University Hospital Leiden, The Netherlands HENK VAN DEN BERG, MD, paediatrician

Department of Infectious Diseases, Municipal Health Service, Amsterdam, The Netherlands

ROEL A COUTINHO, MD, PHD, virologist and head of department

Correspondence to: Dr J M A Lange, Department of Virology, Room L1-153, Academic Medical Centre of the University of Amsterdam, Meibergdreef 15, 1105 AZ Amsterdam, The Netherlands. antigenaemia. HIV antigen was almost constantly present in the serum (26 of 28 samples) of five children who developed AIDS related complex or AIDS and less often in the serum (four of 10 samples) of four children who remained free of symptoms. The two children who developed AIDS showed a virtual absence of antibody reactivity to 24 .

These results indicate that increased HIV gene expression is a contributing factor to the development of AIDS and also provide evidence for a switch from latent to active HIV infection.

\section{Introduction}

Human immunodeficiency virus (HIV), formerly called lymphadenopathy associated virus (LAV) or human T lymphotropic virus type III. (HTLV-III), ${ }^{\perp}$ is the causative agent of the acquired immune deficiency syndrome (AIDS). ${ }^{2}$ As time passes an increasing proportion of people infected with HIV seems to be developing serious clinical disease (AIDS related complex, AIDS, neurological syndromes, or a combination of the three). ${ }^{3.5}$ Disease state has been associated with a particular serological profile, and a reduced incidence of detectable antibodies to the major HIV core protein, p24, in patients with AIDS compared with that in other people infected with HIV has been reported..$^{6-10}$ In a longitudinal study the development of AIDS was preceded by a decline in antibody titre to p24. ${ }^{11}$ In a recent study AIDS seemed to be strongly associated with the expression of HIV antigen in serum as detected by a new test. ${ }^{12}$

In this study we correlated the presence of antigenaemia during infection with HIV with profiles of IgG recognition of HIV proteins and with the clinical outcome in 13 homosexual men who were followed up from seroconversion and in nine children who were all infected with HIV by plasma transfusion from a single donor.

\section{Subjects and methods}

SUBJECTS

Sequential serum samples from 13 homosexual men with sexually acquired HIV infection who have previously been reported on ${ }^{11}$ were 


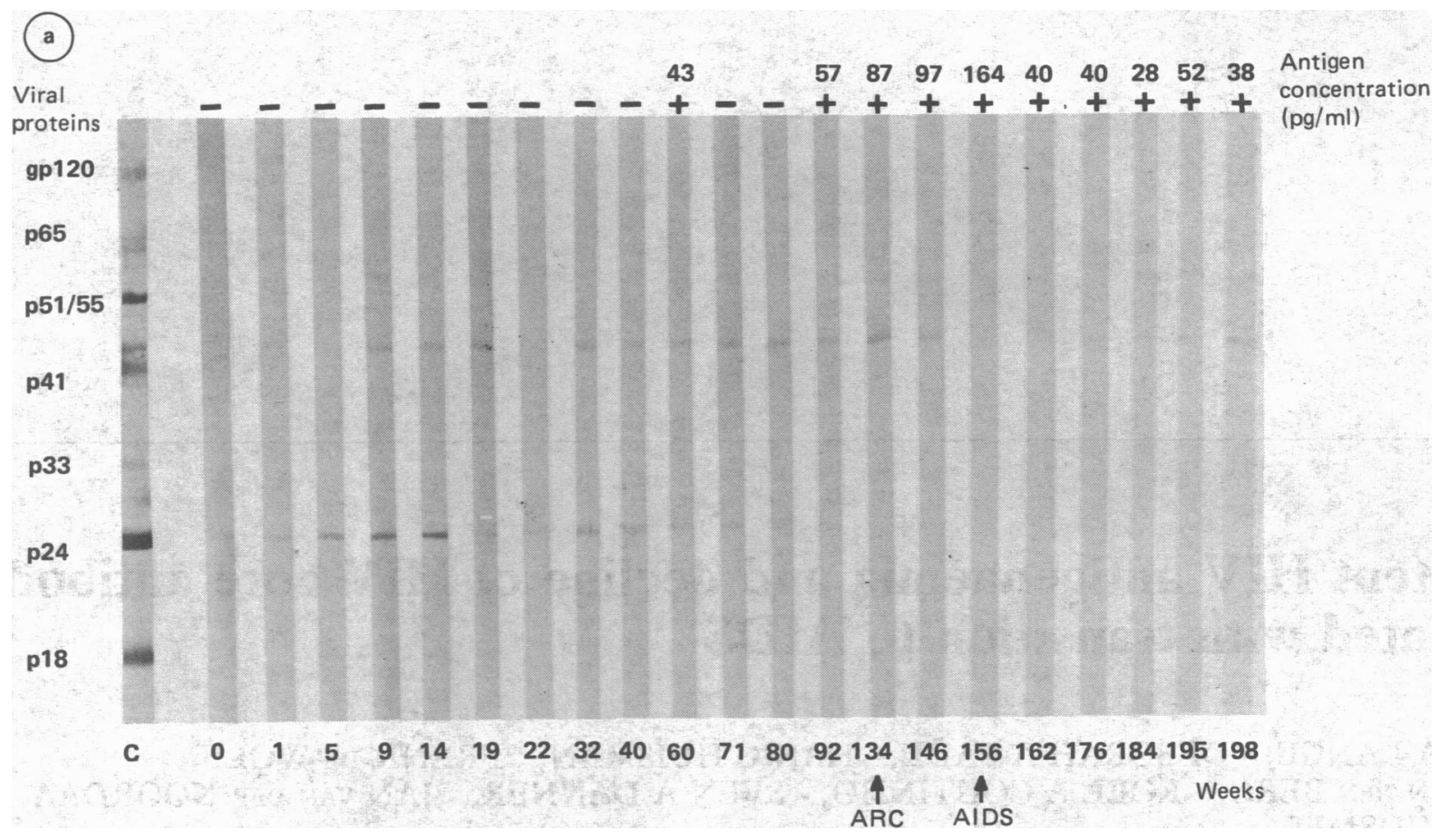

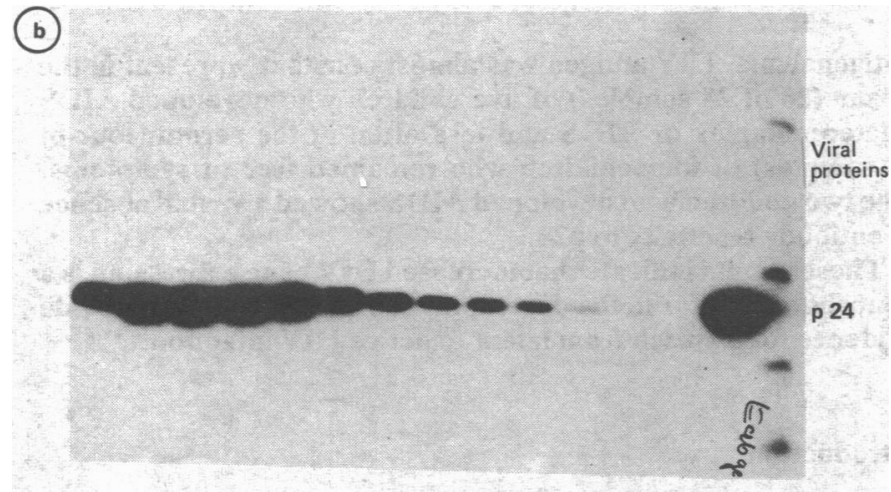

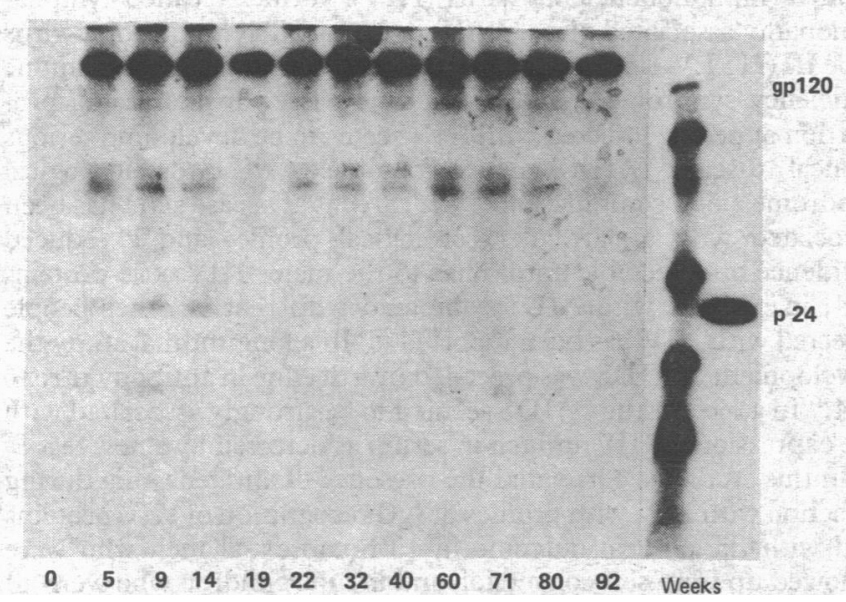

FIG $1-(a)$ HIV antigen concentration related to immunoblot IgG antibody recognition patterns of HIV proteins in consecutive serum samples of homosexual man who developed AIDS at 156 weeks and died at 198 weeks after seroconversion. Time of first immunoblot positive serum sample was taken as point zero and moment of seroconversion. ARC=AIDS related complex. (b) IgG antibody recognition patterns of HIV proteins found by ${ }^{125}$ I-radioimmunoprecipitation assay before (top) and after (bottom) enrichment of glycoproteins in consecutive serum samples from same man. studied. These men, who participated in a study of the efficacy of hepatitis B vaccine, had seroconverted for HIV from 1980 to $1982 . .^{13}$ Blood was collected at monthly intervals during the first five months of the trial and every three months thereafter. One man developed AIDS three years after seroconversion. Six men entered a new prospective study on AIDS that started in October 1984. In this trial blood was collected about every three months. The mean follow up time after seroconversion for the 13 men was 124.5 (range 12-223) weeks. Except for the man who developed AIDS no one developed serious clinical symptoms during follow up.

In addition, serum samples from nine children with HIV infection acquired by transfusion who have previously been reported on ${ }^{15}$ were studied. From 1 April to 5 August 1981, at ages ranging from 2 days to 24 days, they had all received one or more transfusions of plasma from a single donor, who had donated on 31 March 1981 and was later shown to be seropositive for HIV. Up to April 1986 the donor and four of the children had remained healthy, three children had developed AIDS related complex (two aged 10 months and one aged 28.5 months), and two children had died from AIDS (aged 26.5 months and 30.5 months).

\section{IMMUNOBLOT ANALYSIS}

IgG recognition patterns of individual viral proteins were studied with purified HIV as an antigen as described previously. ${ }^{11}$ Proteins p18, p24, and pr 55 were considered to be encoded by the gag gene, proteins $\mathrm{p} 41$ and gp120 by the env gene, ${ }^{16}$ and proteins $\mathrm{p} 33, \mathrm{p} 51$, and $\mathrm{p} 65$ by the pol gene. ${ }^{17} 18$

\section{RADIOIMMUNOPRECIPITATION ASSAY}

In addition to immunoblot analysis of all serum several samples from five of the homosexual men were analysed by iodine- 125 radioimmunoprecipitation assay before and after enrichment for glycoproteins by lentil lectin affinity chromatography (H G Huisman $e t a l$, unpublished). In brief, HIV purified on a sucrose gradient was radiolabelled in the presence of Triton X-100. ${ }^{19}$ In a typical experiment ${ }^{125}$ I-viral proteins (about 100000 cpm per assay, which corresponds to $25 \mathrm{ng}$ protein) dissolved in $50 \mathrm{mM}$ brometamol (TRIS) hydrochloric acid ( $\mathrm{pH} \mathrm{7.5)} \mathrm{containing} 0.5 \mathrm{M}$ sodium chloride, $2 \%$ weight/volume bovine serum albumin, $0.5 \%$ volume/volume Triton X-100, and $0.02 \%$ volume/volume Tween 20 were incubated with $5 \mu \mathrm{l}$ serum for 16 hours at $4^{\circ} \mathrm{C}$. The immunocomplexes that formed were bound to protein A Sepharose beads (Pharmacia Inc, Piscataway, New Jersey, USA) and washed, and the putative bound radiolabelled viral 
proteins were analysed by gel electrophoresis, on a $12.5 \%$ polyacrylamide slab gel in the presence of sodium dodecyl sulphate, and autoradiography.

To enrich the glycoproteins from HIV proteins purified ${ }^{125}$ I-HIV proteins were bound to lentil lectin-Sepharose beads in the presence of $0.5 \%$ Triton $\mathrm{X}-100$. After three successive washings with a solution containing $50 \mathrm{mM}$ TRIS hydrochloric acid ( $\mathrm{pH} 7 \cdot 5$ ), $10 \mathrm{mM}$ calcium chloride, $250 \mathrm{mM}$ sodium chloride, and $0.5 \%$ Triton X-100 glycoproteins were eluted with $0.3 \mathrm{M}$ a-methyl-D-mannoside and applied in the ${ }^{125}$ I-radioimmunoprecipitation assay.

\section{HIV ANTIGEN DETECTION}

Serum samples were assayed for HIV antigen by a solid phase immunoassay as described previously. ${ }^{12} \mathrm{~A}$ sample of $200 \mu \mathrm{l}$ was incubated overnight at room temperature with a human anti-HIV coated bead. The beads were washed with distilled water and rabbit anti-HIV IgG was added and incubated for four hours at $45^{\circ} \mathrm{C}$. The beads were washed as before and then incubated for two hours at $45^{\circ} \mathrm{C}$ with goat anti-rabbit IgG conjugated to horseradish peroxidase. After a final wash the beads were transferred to tubes, and $O$-phenylenediamine was added and allowed to react for 30 minutes at room temperature in the dark. The reaction was stopped with $1 \mathrm{ml} 1 \mathrm{~N}$ sulphuric acid, and the absorbance at $429 \mathrm{~nm}$ was read with the Quantum dual wavelength spectrophometer. A sample was considered to be positive for HIV antigen if its optical density was greater than or equal to 0.05 plus the mean of five duplicates of normal human plasma.

This assay is most sensitive for the core antigen of HIV: purified core antigen is detectable at about $50 \mathrm{pg} / \mathrm{ml}$ when spiked into serum or plasma. In this study we calculated the HIV antigen concentration from a standard curve for purified viral proteins.

\section{Results}

Only two of the 13 seroconverted homosexual men had detectable concentrations of HIV antigen in their serum, one of whom developed AIDS. Figure 1 shows the IgG recognition patterns of HIV proteins related to HIV antigenaemia in sequential serum samples from the homosexual man who eventually developed AIDS. The immunoblot (fig $1(a)$ ) shows that before the onset of AIDS there is a striking decline in reactivity to p24gag while reactivity to $\mathrm{p} 41$, encoded by the env gene, remains fairly constant. The decline in reactivity to p24 is seen just as clearly in the ${ }^{125} \mathrm{I}-$ radioimmunoprecipitation assay (fig $1(b)$ ) while reactivity to gp 120 , which is encoded by the env gene and is not detected well in the immunoblot analysis, does not decline. The decline in p24 recognition coincides with the appearance and persistence of HIV antigenaemia.

In only one of 117 serum samples taken after seroconversion from the 12 "healthy" homosexual men was antigen $(40 \mathrm{pg} / \mathrm{ml})$ detected. This sample was taken 41 weeks after seroconversion of the subject. Later negative samples from this man were taken at 48,54 , and 157.5 weeks, after which he was lost to further follow up. All of the 12 healthy men showed persistent strong recognition of $\mathrm{p} 24$ in all serum samples, as has been reported before. ${ }^{11}$ In the four men for whom ${ }^{125}$ I radioimmunoprecipitation assays were done the results paralleled those of the immunoblot studies (data not shown).

Figure 2 shows the IgG recognition patterns of HIV proteins and the data on HIV antigens from the serum of the nine children with infection acquired by transfusion as well as from a recent serum sample from the plasma donor. The donor (designated X) and children A, B, C, and D had not yet developed serious AIDS related symptoms. In three of these five subjects HIV antigen was detected in at least one serum sample, but no consistent pattern of HIV antigenaemia was found, with four of 11 samples yielding positive results. The donor and children B, C, and D had initially strong or increasing IgG reactivity to 24

Children $\mathrm{E}, \mathrm{F}$, and $\mathrm{G}$ developed AIDS related complex at the ages of 10 months, 28.5 months, and 10 months, respectively. HIV antigen was found in 19 of 21 serum samples that were tested from these children. Serum from child $E$ showed persistent strong IgG reactivity to $p 24$, but consecutive samples from children $F$ and $G$ showed weak or no reactivity to 224 . Child $H$ suffered from progressive encephalopathy and died from myocarditis aged 30.5 months. AIDS could not officially be diagnosed, however, until the antigen test became available, as no antibodies to HIV could be shown in the two serum samples (taken at ages 25.5 months and 26 months) that were left from this child. One of these samples has not been tested, but the other has since shown a strong presence of HIV antigen. All six consecutive serum samples from child I, who died aged 26.5 months, showed strong persistence of HIV antigenaemia and declining IgG reactivity to p24.

\section{Discussion}

Persistent HIV antigenaemia preceded the onset of AIDS in a homosexual man who was followed up from seroconversion until his death. None of 12 healthy homosexual men who were followed up from seroconversion had persistent HIV antigenaemia. In nine children who were infected with HIV by plasma transfusion in 1981 persistent expression of HIV antigen seemed also to indicate serious clinical disease.

Anti-p24 reactivity often decreased concomitantly with the persistence of HIV antigenaemia and thus probably indicated the clearance of antibodies by excess viral antigen, as has been suggested before. ${ }^{120}$ The same mechanism might have caused the complete absence of antibodies to HIV in one of the children with AIDS and in similar cases reported by others. ${ }^{2021}$

AIDS or the transition to AIDS is presumably preceded by enhanced expression of viral genes. The synthesis of HIV structural proteins seems to be controlled after transcription by the expression of the newly discovered tat-III (transcriptional trans-activation) and

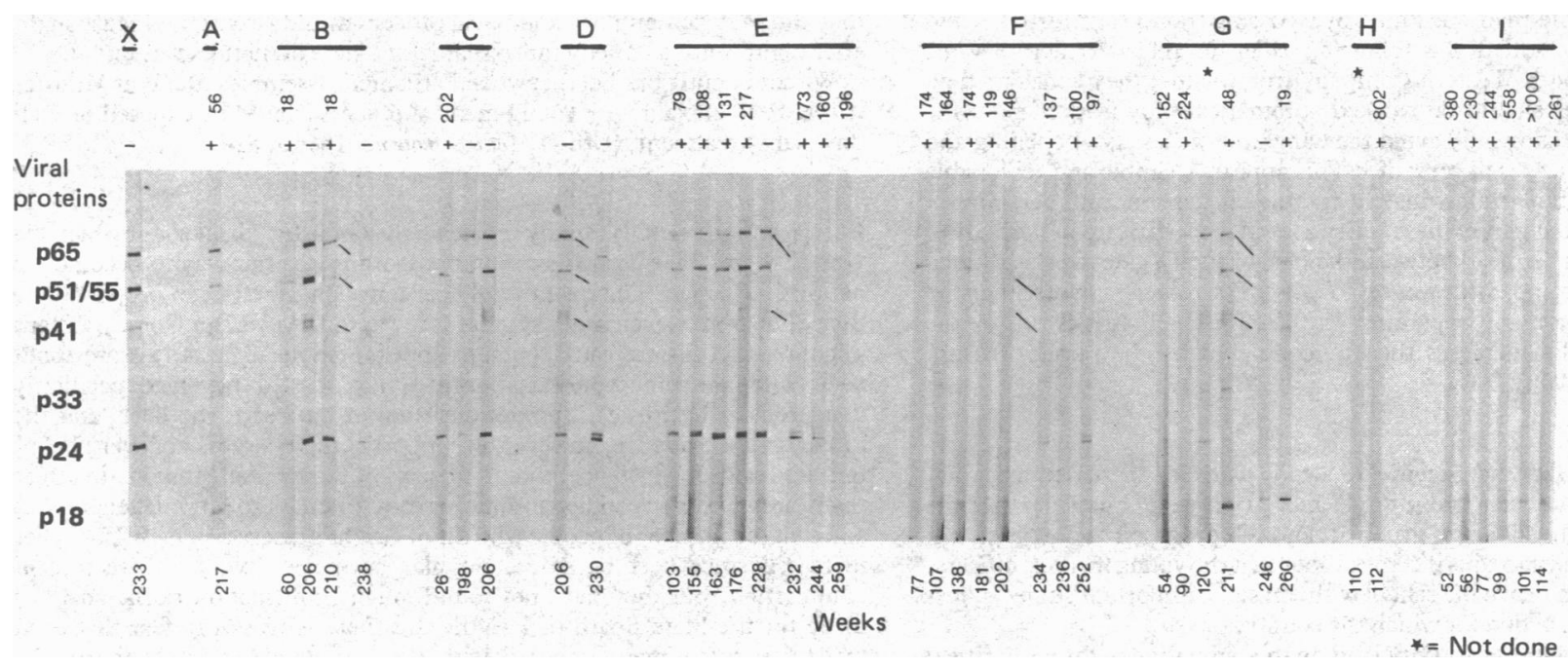

FIG 2-HIV antigen concentrations related to IgG recognition patterns of viral proteins (immunoblot analysis) in serum samples from a plasma donor (X) and nine children (A to I). Weeks at bottom denote time after birth for children and time after donation for donor. Immunoblot analysis was performed at two sessions. Serum Samples B4, D2, E6-8, F6-8, and G5-6 were tested separately.

$\star$ Samples not tested owing to lack of serum. 
art (anti-repression trans-activator) genes. ${ }^{2223} \mathrm{~A}$ latent state of infection by HIV would be characterised by a lack of function of tat-III or art, or both, and an active infection by activation of the function of tat III or art, or both. ${ }^{23}$ Folks et al found a long latent period for HIV infection in a small proportion of cells of an infected $T$ cell line with a switch to active viral replication after they had been treated with 5 -iodo- 2 'deoxyuridine. ${ }^{2+}$ The results of our study indicate that transition from a latent to an active state of infection is probably also operative in vivo, as persistently augmented expression of HIV genes-that is, the presence of HIV antigen-signified serious clinical disease.

The high incidence of detectable HIV antigen in children who do not have clinical symptoms compared with that in "healthy" adults might reflect a more delicate balance between active and latent HIV infection in children. This is corroborated by the fact that infected infants are more likely to develop serious HIV related disease than adults. ${ }^{1525}$

Whether the production of HIV antigen accurately reflects complete viral replication with the production of infectious virions is still to be investigated.

We gratefully acknowledge the generous cooperation of Professor Dr L J Dooren, Professor Dr J M J J Vossen, and Dr W Kuis (department of paediatrics, University Hospital Leiden and Wilhelmina Children's Hospital, University of Utrecht). This study was partly supported by The Netherlands Foundation for Preventive Medicine.

\section{References}

1 Coffin J, Haase A, Levy JA, et al. What to call the AIDS virus? Nature 1986;321:10. 2 Wong-Staal F, Gallo RC. Human T-lymphotropic retroviruses. Nature 1985;317:395-403. 3 Goedert JJ, Biggar RJ, Weiss SH, et al. Three-year incidence of AIDS in five cohorts of HTLVIII-infected risk group members. Science 1986;231:992-5.

4 Melbye M, Biggar RJ, Ebbesen P, et al. Long-term seropositivity for human T-lymphotropic virus type III in homosexual men without the acquired immunodeficiency syndrome: virus type III in homosexual men without the acquired immunodeficiency syndrom
development of immunologic and clinical abnormalities. Ann Intern Med 1986;104:496-500

5 Ho DD, Rota TR, Schooley RT, et al. Isolation of HTLV-III from cerebrospinal fluid and neural tissues of patients with neurologic syndromes related to the acquired immunodeficiency syndrome. N Engl F Med 1985;313:1493-7.
6 Kalyanaraman VS, Cabradilla CD, Getchell JP, et al. Antibodies to the core protein of lymphadenopathy-associated virus (LAV) in patients with AIDS. Science 1984;225:321-3. Schüpbach J, Haller O, Vogt M, et al. Antibodies to HTLV-III in Swiss patients with AIDS and pre-AIDS and in groups at risk for AIDS. $N$ Engl F Med 1985;312:265-70.

8 Barin F, McLane MF, Allan JS, Lee TH, Groopman JE, Essex M. Virus envelope protein of HTLV-III represents major target antigen for antibodies in AIDS patients. Science 1985;228: 1094-6.

9 Casey JM, Kim Y, Andersen PR, Watson KF, Fox JL, Devare SG. Human T-cell lymphotropic virus type III: immunologic characterization and primary structure analysis of the major internal protein p24. 7 Virol 1985;55:417-23.

10 Kitchen L, Malone G, Orgad S, et al. Viral envelope protein of HTLV-III is the major target antigen for antibodies in hemophiliac patients. F Infect Dis 1986;153:788-90.

11 Lange JMA, Coutinho RA, Krone WJA, et al. Distinct IgG recognition patterns during progression of subclinical infection with lymphadenopathy associated virus/human $\mathrm{T}$ lymphoprogression of subchinical infection with

12 Goudsmit J, de Wolf F, Paul DA, et al. Expression of human immunodeficiency virus antigen HIV-Ag) in serum and cerebrospinal fluid during acute and chronic infection. Lancet 1986;ii: 177-80.

13 Coutinho RA, Lelie PN, Albrecht-van Lent P, et al. Efficacy of a heat-inactivated hepatitis B vaccine in male homosexuals: outcome of a placebo controlled double blind trial. Br Med $\mathcal{f}$ 1983;286:1305-8.

14 Coutinho RA, Krone WJA, Smit L, et al. Introduction of lymphadenopathy associated virus or human T-lymphotropic virus (LAV/HTLV-III) into the male homosexual community in Amsterdam. Genitourin Med 1986;62:38-43.

15 Lange JMA, van den Berg H, Dooren LJ, Vossen JMJJ, Kuis W, Goudsmit J. LAV/HTLV-III infection in nine children infected by a single plasma donor: outcome and viral protein recognition patterns. F Infect Dis 1986;154:171-44.

16 Essex M, Allan J, Kanki P, et al. Antigens of human T-lymphotropic virus type III lymphadenopathy-associated virus. Ann Intern Med 1985:103:700-3.

17 Di Marzo Veronese F, Copeland TD, DeVico AL, et al. Characterization of highly immunogenic p66/51 as the reverse transcriptase of HTLV-III/LAV. Science 1986;231:1289-91.

18 Steimer KS, Higgins KW, Powers MA, et al. Recombinant polypeptide from the endonuclease region of the acquired immune deficiency syndrome retrovirus polymerase (pol) gene detects region of the acquired immune deficiency syndrome retrovirus polym
serum antibodies in most infected individuals. 7 Virol 1986;58:9-16.

19 Hunter WM, Greenwood FC. Preparation of iodine-131 labelled human growth hormone of high specific activity. Nature 1962;194:495-6

20 Levy JA, Kaminsky LS, Morrow WJW. Infection by the retrovirus associated with the acquired immunodeficiency syndrome: clinical, biological, and molecular features. Ann Intern Med 1985;103:694-9.

21 Groopman JE, Hartzband P, Shulman L, et al. Antibody seronegative human T-lymphotropic virus type III (HTLV-III)-infected patients with acquired immunodeficiency syndrome or related disorders. Blood 1985;66:742-4.

22 Rosen CA, Sodroski JG, Goh WC, Dayton A, Lippke J, Haseltine WA. Post-transcriptional regulation accounts for the trans-activation of the human T-lymphotropic virus type III. Nature 1986;319:555-9.

23 Sodroski J, Goh WC, Rosen C, Dayton A, Terwilliger E, Haseltine W. A second posttranscriptional trans-activator gene required for HIV replication. Nature 1986;321:412-7.

24 Folks T, Powell DM, Lightfoote MM, Benn S, Martin MA, Fauci AS. Induction of HTLV-III LAV from a nonvirus-producing T-cell line: implications for latency. Science 1986;231:600-2.

25 Hardy AM, Allen JR, Morgan WM, Curran JW. The incidence rate of acquired immunodeficiency syndrome in selected populations. FAMA 1985;253:215-20.

(Accepted 28 October 1986)

\section{YEARS AGO}

Level crossings are a standing danger to the public and the railway men; as they cannot be abolished without compelling the railway companies to incur an enormous outlay, it only remains to endeavour to diminish their dangers. Recently, an old gate-man was killed by a passing train near Mortlake, and the coroner's jury added the following rider to their verdict: "While exonerating the South-Western Company from blame, they considered all level crossing gates should be worked automatically by a lever from the gateman's cabin. That would avoid the dangerous necessity of opening and closing gates by hand, as at present." This appears a simple and reasonable recommendation; but, unfortunately for the suggestion, another inquest was held in a different part of the country a few days earlier, upon the body of a little girl who got her head between the bars of such a gate, and was killed when the automatic apparatus was set to work. The remedy is worse than the disease, for the automatic apparatus, if it diminishes the risks run by the gate-men, materially increases those encountered by the public. (British Medical fournal 1886;ii:731.)

It is a well-known fact that, again and again, plans for increased teachingaccommodation have been "submitted" and "approved," but when the time for action comes, the money is grudged, and the proposed "vote" is struck out of the Estimates, and thus it comes about that the young medical officers, session after session, leave the school with, on some important subjects, just one-half of the instruction for which the country pays.

Nor is this all; it appears that England, in the estimation of the authorities, cannot afford to give decent quarters to more than a certain proportion of the surgeons on probation going through the Netley course. At this present time, about twenty of them are distributed in mean lodging-houses in the neighbouring village, to the prejudice of their discipline, to their extreme inconvenience, and exposed to the chance of typhoid fever from unsanitary surroundings. Is this seemly? Is it even decent? Would the Government treat young men going through Sandhurst, the Staff College, the Naval School at Greenwich, or the School of Engineering at Cooper's Hill, in this fashion? If they did, a dozen military and naval officers would rise in the House night after night, until a remedy for so shameful a state of matters was found.

We confidently predict that when Parliament assembles, the War Minister will have to explain why young medical officers should be exposed to such unworthy treatment. (British Medical Fournal 1886;ii:828.)

Beer, it would seem, is rapidly replacing the fantastic "drinks" for which the United States have earned a reputation, and is in a fair way to become the national beverage. The quantity of beer now consumed is, in proportion to the population, eleven times as great as it was forty years ago. Some, perhaps not altogether disinterested, persons appear anxious to get up a scare about beer; and are endeavouring to prove that it is a beverage peculiarly dangerous to health, causing degeneration of the heart, the liver, and the kidneys. The evidence, however, in support of this charge is not overwhelming; it is said, for instance, that the hearts of the men of Munich are larger than those of other people, and more ready to undergo fatty degeneration; and that the number of people who die of Bright's disease, in New York, has increased since beer became a popular beverage. Evil tales are told of adulteration, but they have not found much confirmation in the analyses made for the State Board of Health; and there is reason to fear that even whisky is sometimes tampered with. On the whole, this change in the drinking habits is a matter for congratulation; even if it be true that he who drinks beer thinks beer. Still, our somewhat mercurial cousins may be none the worse for the infusion of a little Teutonic stolidity. There is, however, one kind of ale which is best of all-that of Adam. (British Medical Fournal 1886;i:837.) 